\title{
SPRUCE BUDWORM DAMAGE TO BALSAM FIR IN IMMATURE STANDS, QUEBEC ${ }^{1}$
}

\author{
BY R. J. HATCHER ${ }^{2}$
}

ABSTRACT

A study was made of the effect of the 1945-1957 spruce budworm infestation on 1,800 acres of spruce-fir and spruce-fir-hardwood forest logged for pulpwood about 15 years prior to the infestation.

The number of fir trees was reduced 64 per cent between 1951 and 1961 in the main cover type representing 69 per cent of the forest; fir was reduced from a major stand component of 45 per cent by volume to a minor component of 11 per cent. The basal area reduction of fir varied directly with the fir basal area at the time of the outbreak. Losses were very high in stands containing over $20 \mathrm{sq}$. $\mathrm{ft}$. of fir per acre.

These young stands did not exhibit the degree of resistance to damage often observed in young stands elsewhere. But in spite of heavy losses through all diameter classes, the amount of spruce and fir regeneration that survived to 1961 is believed adequate to produce a pulpwood crop within 60 years.

INTRODUCTION

Forest managers in eastern Canada are keenly intersted in how well their forests recover from the recent spruce budworm (Choristoneura fumiferana (Clem.)) infestation and in any changes in species composition that result therefrom. Failure to regenerate or substantial alteration in stand composition could be of profound economic significance.

Studies in mature balsam fir forests devastated by the budworm indicate that over 95 per cent fir mortality may occur but that, in general, more than enough fir seedlings survive to assure well stocked future stands (Blais 1954, Ghent et al. 1957, Vincent 1962). However, there is little information available on budworm damage in young and immature stands. This report presents the results of 1951 and 1961 measurements in stands of black spruce, spruce-fir, and spruce-fir-hardwoods that originated from a pulpwood logging in 1932-34, and which were attacked by the spruce budworm from 1945 to 1957.

Forest Description ${ }^{3}$

The Vermillion River Observation Area is one of 14 five-square-mile cut-over areas in Quebec which the Forest Research Branch has studied since 1948. The purpose of these study areas is to provide data on regeneration, growth, and yield for use in management of second-growth stands. Plots are remeasured at ten-year intervals.

The study area occupies 1,800 acres of a north-south ridge $(1,400$ feet elevation), plus the lower slopes surrounding the ridge, near the junction of Creek Gagnon and the Vermillion River $\left(47^{\circ} 15^{\prime}\right.$ N., $73^{\circ} 40^{\prime}$ W.) 15 miles west of the Consolidated Paper Corporation Straw Hat Depot and 90 miles

\footnotetext{
${ }^{2}$ Department of Forestry, Canada, Forest Research Branch Contribution No. 593.

${ }^{2}$ Research Officer, For. Res. Br., Dept. of Forestry, Box 35, Sillery, P.Q.

"Nomenclature as in "Native Trees of Canada", Bulletin 61. Canada, Department of Forestry, 6 th edition, 1961.
} 
northwest of Trois-Rivières. The forest is typical of Forest Section B.7, the predominant cover type of which is a mixedwood association of fir, black spruce, white birch and scattered white spruce and aspen (Rowe 1959). As a result of the recent ravages of birch dieback and spruce budworm there are vast areas of open, snag- and blowdown-filled forest in which a proliferation of mountain maple, hazel, (Corylus cornuta Marsh.) pin cherry and raspberry (Rubus Idaeus L.) retard conifer regeneration.

The forest was classified in 1951 according to four cover types with differing species composition (Table 1). The pure softwood stands of the Black Spruce type (bS) represent 7 per cent of the area and are confined to the low flat areas where drainage is retarded. The Spruce-Fir type (SF) represents 9 per cent of the area and is found on gentle lower slopes between the SFwB and bS types. Spruce is mostly black spruce in this and the bS type. The Spruce-Fir-White Birch type (SFwB) is a mixedwood occupying the well-drained middle and upper slopes of the ridge and represents 69 per cent of the area. The remaining 15 per cent is the Spruce-Fir-Sugar Maple type (SFsM), a mixedwood confined to the drier ridge top and the only type containing sugar maple. Spruce in this and the SFwB type is mostly white spruce.

TABLE 1

Species Per Cent Of Total Basal Area, By Cover Types, 1951

\begin{tabular}{lcccccccc}
\hline $\begin{array}{c}\text { Cover } \\
\text { Type }\end{array}$ & Fir & Snruce & $\begin{array}{c}\text { Other } \\
\text { Conifers }\end{array}$ & $\begin{array}{c}\text { White } \\
\text { Birch }\end{array}$ & Aspen & $\begin{array}{c}\text { Yellow } \\
\text { Birch }\end{array}$ & $\begin{array}{c}\text { Sugar } \\
\text { Maple }\end{array}$ & $\begin{array}{c}\text { Red } \\
\text { Maple }\end{array}$ \\
\hline bS & 17 & 82 & $\mathbf{1}$ & 0 & 0 & 0 & 0 & $\mathbf{0}$ \\
SF & 35 & 50 & 2 & 3 & 10 & 0 & 0 & 0 \\
SFwB & 56 & 8 & 2 & 26 & 6 & $\mathbf{1}$ & 0 & $\mathbf{1}$ \\
SFsM & 30 & 6 & 0 & 22 & 9 & 3 & $\mathbf{1 7}$ & 13 \\
\hline
\end{tabular}

The area is a small part of the extensive forest of the St. Maurice Valley that was logged for white and red pine sawlogs about the turn of the century, and relogged for spruce and fir pulpwood since the late twenties.

The study area was logged between 1932 and 1934 and the spruce-fir volumes removed were estimated from the 1951 stump measurements as follows:

$\begin{array}{lc}\text { Cover Type } & \text { Spruce and Fir Cut, 1932-34, } \\ \text { bS } & \text { Cubic Feet per Acre } \\ \text { SF } & 890 \\ \text { SFwB } & 1,170 \\ \text { SFsM } & 600 \\ & 160\end{array}$

The precise structure of the stands immediately before logging is not known but the diameter class distribution of both residual trees and stumps in 1951 indicate an uneven-aged structure. Cutting was controlled in mixed-

\footnotetext{
A report on the establishment of observation area number 7, Vermillion River, 1951, by A. F. Berg. Forest Research Branch Binder No. 836.
} 
wood stands by a stump diameter limit of 6 inches below which trees could not be cut; no such control was imposed in softwood stands.

The amount of fir present when the budworm arrived on the scene in about 1945 can only be estimated from the 1951 data. In the SFwB cover type (69 per cent of the area), of the 142 fir per acre larger than 3.5 inches d.b.h. (Table 2), 113 were between 3.6 and 6.5 inches. Although logging did not completely change the uneven-aged conifer structure, at the advent of the budworm attack the bulk of the insect's food was represented by fir trees below 6.5 inches d.b.h. ${ }^{5}$

The recent spruce budworm infestation, reported to have first reached outbreak proportions in Quebec in 1939 (Pilon and Blais 1961), spread eastward and reached the study area in 1945. The attack in this part of Quebec was marked by two waves of severe defoliation, from 1946 to 1948 and from 1953 to 1956 . During the intervening years, defoliation was light to moderate and the infestation ended in 1957.

\section{METHOD OF STUdY}

In 1951, 146 permanent, square, tenth-acre line plots were systematically established on a 10-chain grid.

The following data were recorded on each plot: 1) all trees 0.6 inch d.b.h. and larger were tallied by species and one-inch diameter classes, 2) dead trees judged to have died during the preceding decade were tallied by species and one-inch diameter classes and scribed with an "X", 3) a stocked quadrat tally of regeneration was made on 20 milacre quadrats, 4) height-diameter measurements were made in order to construct local volume tables, 5) stump diameters were tallied and converted to d.b.h.

In 1961, items 1) and 2) above were repeated. Many one and twoinch-fir probably died and disappeared since 1951 so that the 1961 sapling mortality estimate would be low although the effect of these missing stems on mortality volume estimates would not be great. A stocked quadrat regeneration survey was done on 10 milacres on each plot and per cent values were converted to number of seedlings per acre using Ray's (1948) graph.

\section{Results}

Stand development after the 1932-34 logging was quite satisfactory until the early 1940 's judging by the number of conifers estimated in 1951 (Table 2) The spruce budworm, which began feeding in about 1945, caused severe defoliation but very little mortality up to 1951 (Figure 1). Heavy losses only began after 1951 and by 1961 fir mortality ranged up to $474 \mathrm{cu}$. ft. per acre (Table 3, Figure 2). The result has been a reduction of fir from a major to a minor volume component, particularly in the mixedwood types which represent 84 per cent of the forest (Figure 3).

Spruce apparently resisted the budworm better than fir as suggested by spruce increases in both absolute and proportional values for numbers of trees and volume (Table 2, Figure 3).

\footnotetext{
Source: 1944-53 Annual Reports, Forest Insect and Disease Survey, Can. Dept. of Agriculture; 1954-57 Reports of the Forest Insect Survey in the Province of Quebec, Bureau of Entomology, Quebec Department of Lands and Forests.
} 


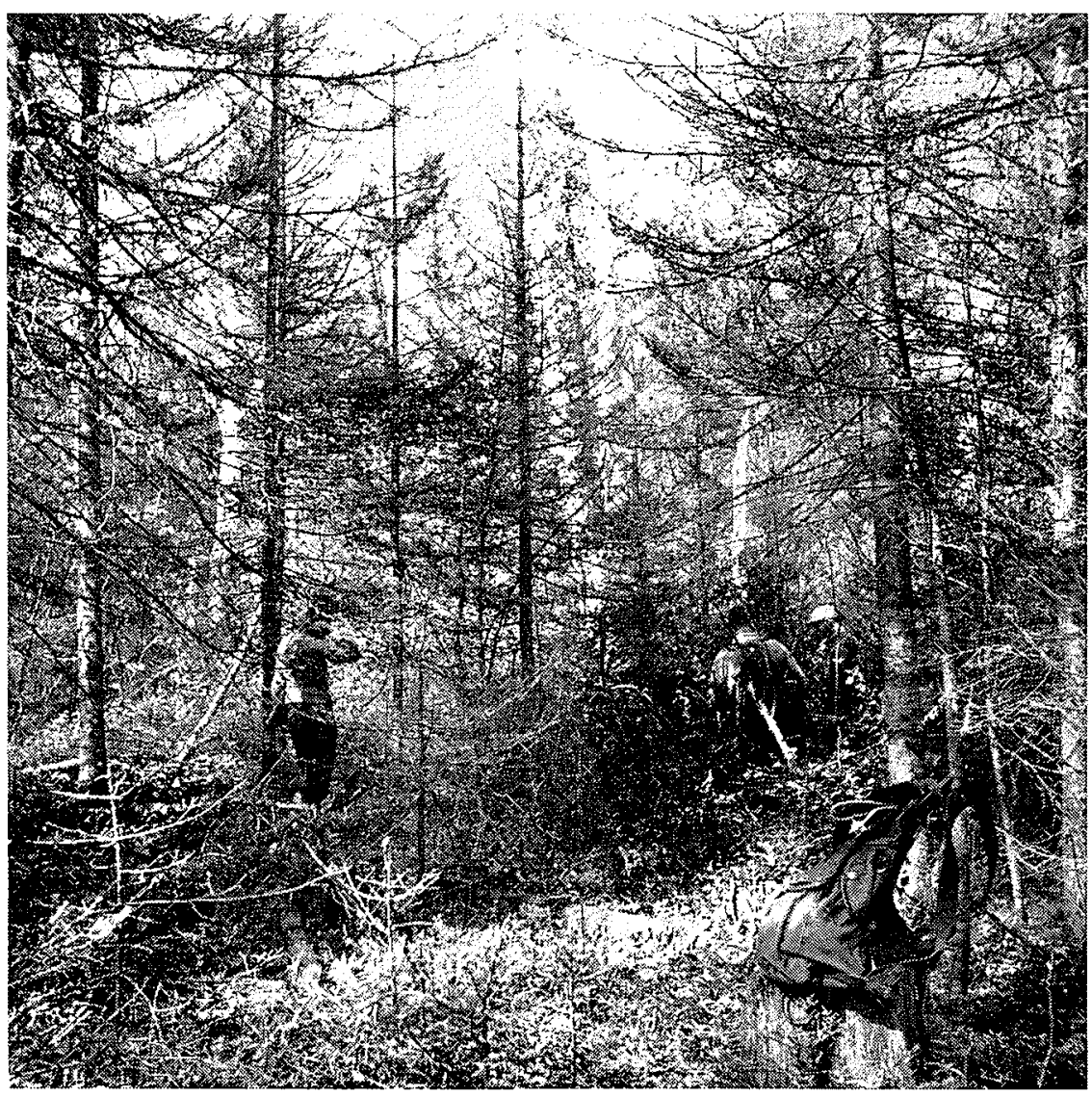

FIGURE 1. Fir severely defoliated by the spruce budworm but still living, 1951.

The percentage changes in numbers of stems suggest that fir losses were higher in mixedwood than in softwood stands (Table 2). Attempts to explain this observation led to examination of the possible dependence of fir mortality on several stand variables. The scattergrams for individual plot values did not indicate significant relationships between mortality and the proportion of fir in the stand, or between mortality and fir basal area in the original stand. However, a significant regression line was found for the SFwB type when the fir basal area in 1961 was plotted over fir basal area in 1951. The transformation of the dependent variable into per cent change in fir basal area for the period 1951-61, changed the linear regression equation into a curvilinear equation. The relationship shows an increase in basal area for initial basal areas below about $10 \mathrm{sq}$. ft. and changing to a decrease for plots above $10 \mathrm{sq}$. ft. and larger decreases for greater initial basal 


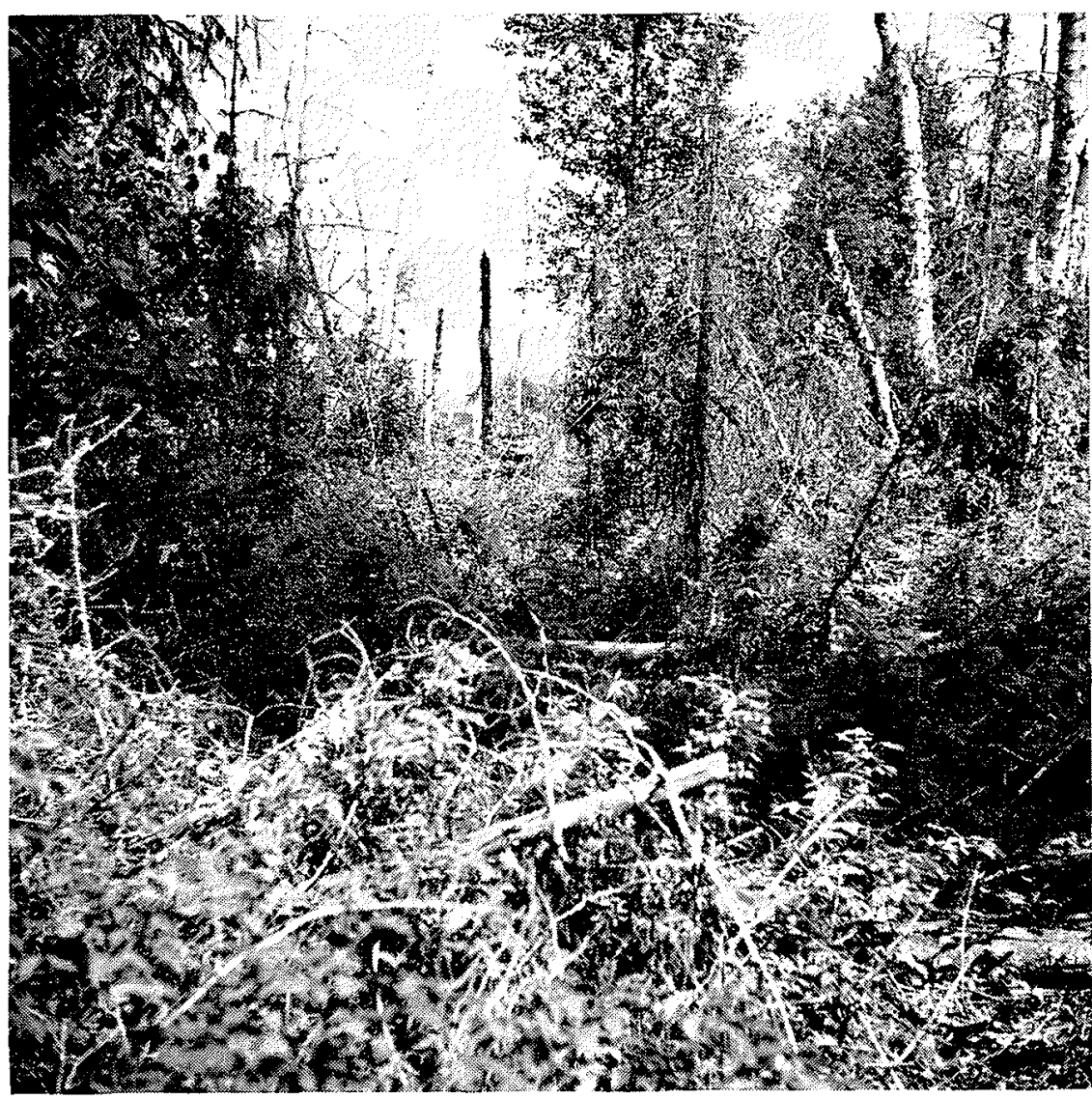

FIGURE 2. Typical scene of devastation in mixedwood stands in 1961. Surviving conifers are hidden in tangle of blowdown and shrubs.

areas (Figure 4). Because of the small range in basal area covered by the bS and SF types no attempt was made to find a similar relationship but the average basal area reductions for these types were plotted as single points on the scattergram of individual SFwB plots (Figure 4). The position of these points relative to the curve for the SFwB type suggests that losses in softwood types were much greater than in the SFwB. The mixedwood apparently suffered higher losses because of larger fir basal areas and actually may be somewhat more resistant to damage than softwood stands, at least when basal areas are small.

Examination of the changes in the numbers of fir trees would indicate that saplings resisted the budworm better than larger trees (Table 2). Reduction in number of saplings was more pronounced in the mixedwood than in the softwood types; in fact, in the softwood types the numbers of one- and 


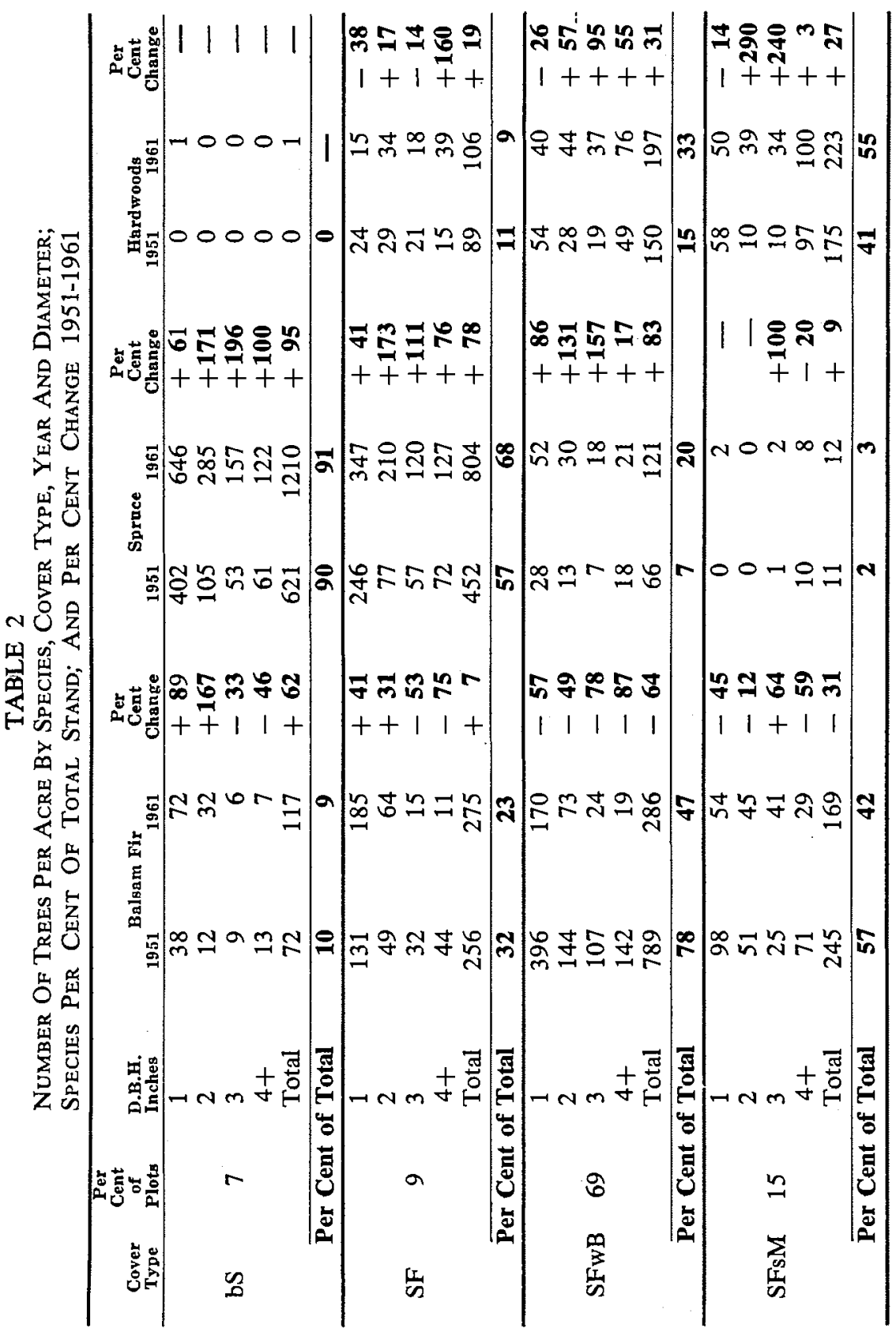


TABLE 3
Volume Of Mortality By Species And Cover Type, ONe INCH D.B.H. ANd Over $1942-1951$ AND $1952-1961$

\begin{tabular}{lrrrrrr}
\hline $\begin{array}{c}\text { Cover } \\
\text { type }\end{array}$ & Period & Fir & Spruce & Birch & Maple & $\begin{array}{c}\text { Other } \\
\text { specles }\end{array}$ \\
\hline \multirow{2}{*}{ bS } & $1942-51$ & 1 & 0 & 0 & 0 & 0 \\
& $1952-61$ & 26 & 29 & 0 & 0 & 0 \\
SF & $1942-51$ & 1 & 1 & 2 & 0 & 1 \\
& $1952-61$ & 108 & 35 & 21 & 0 & 9 \\
SFwB & $1942-51$ & 10 & 1 & 58 & 0 & 5 \\
& $1952-61$ & 474 & 49 & 201 & 5 & 69 \\
SFsM & $1942-51$ & 1 & 0 & 0 & 0 & 1 \\
& $1952-61$ & 256 & 16 & 119 & 71 & 26 \\
\hline
\end{tabular}

TABLE 4

Number Of Seedlings (Less Than 0.6 Inch D.B.H.) ANd Saplings (0.6-3.5 Inches D.B.H.) By Species And Cover Type, 1961

\begin{tabular}{clrrrrr}
\hline \multirow{2}{*}{$\begin{array}{c}\text { Cover } \\
\text { type }\end{array}$} & \multicolumn{1}{c}{$\begin{array}{c}\text { Size } \\
\text { Class }\end{array}$} & Fir & Spruce & Birch & Maple & $\begin{array}{c}\text { other } \\
\text { species }\end{array}$ \\
\hline bS & Seedling & 300 & 350 & 0 & 0 & 0 \\
& Sapling & 110 & 1088 & 1 & 0 & 18 \\
\cline { 2 - 8 } & TOTAL & 410 & 1438 & 1 & 0 & 18 \\
SF & Seedling & 500 & 375 & 0 & 0 & 250 \\
& Sapling & 264 & 677 & 17 & 0 & 65 \\
\cline { 2 - 8 } & TOTAL & 764 & 1052 & 17 & 0 & 315 \\
SFwB & Seedling & 825 & 225 & 225 & 125 & 250 \\
& Sapling & 267 & 100 & 76 & 12 & 34 \\
\cline { 2 - 8 } & TOTAL & 1092 & 325 & 301 & 137 & 284 \\
\multirow{2}{*}{ SFsM } & Seedling & 1425 & 175 & 175 & 2575 & 0 \\
& Sapling & 140 & 5 & 17 & 106 & 1 \\
\hline & TOTAL & 1565 & 180 & 192 & 2681 & 1 \\
\hline
\end{tabular}


195
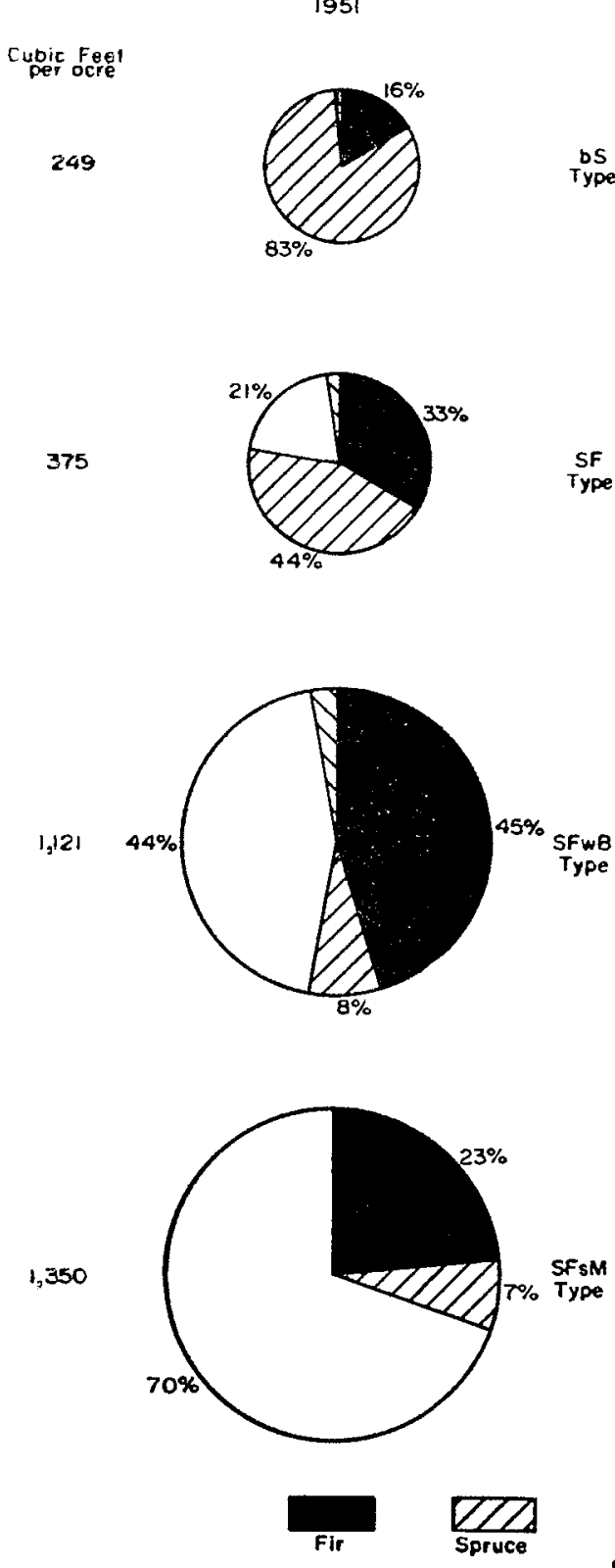

1961

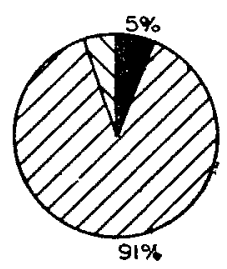

Cubic Fee
per ocre

436

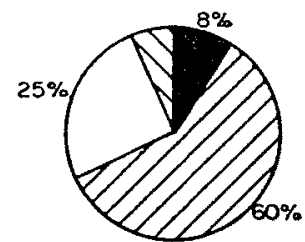

499

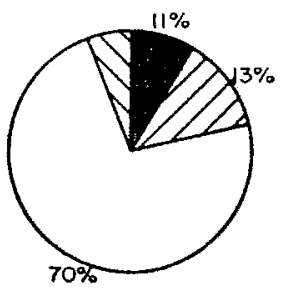

651
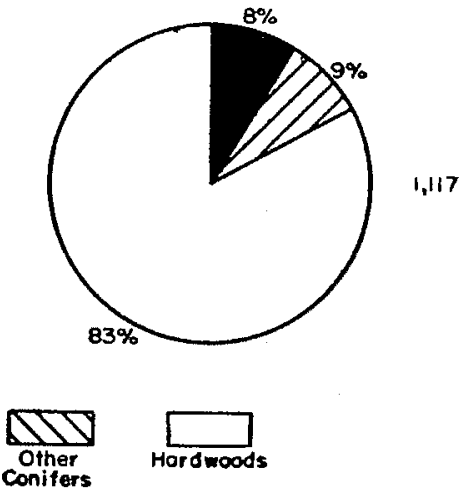

FJGURE 3. Total volume and species per cent of total volume, 1951 and 1961 


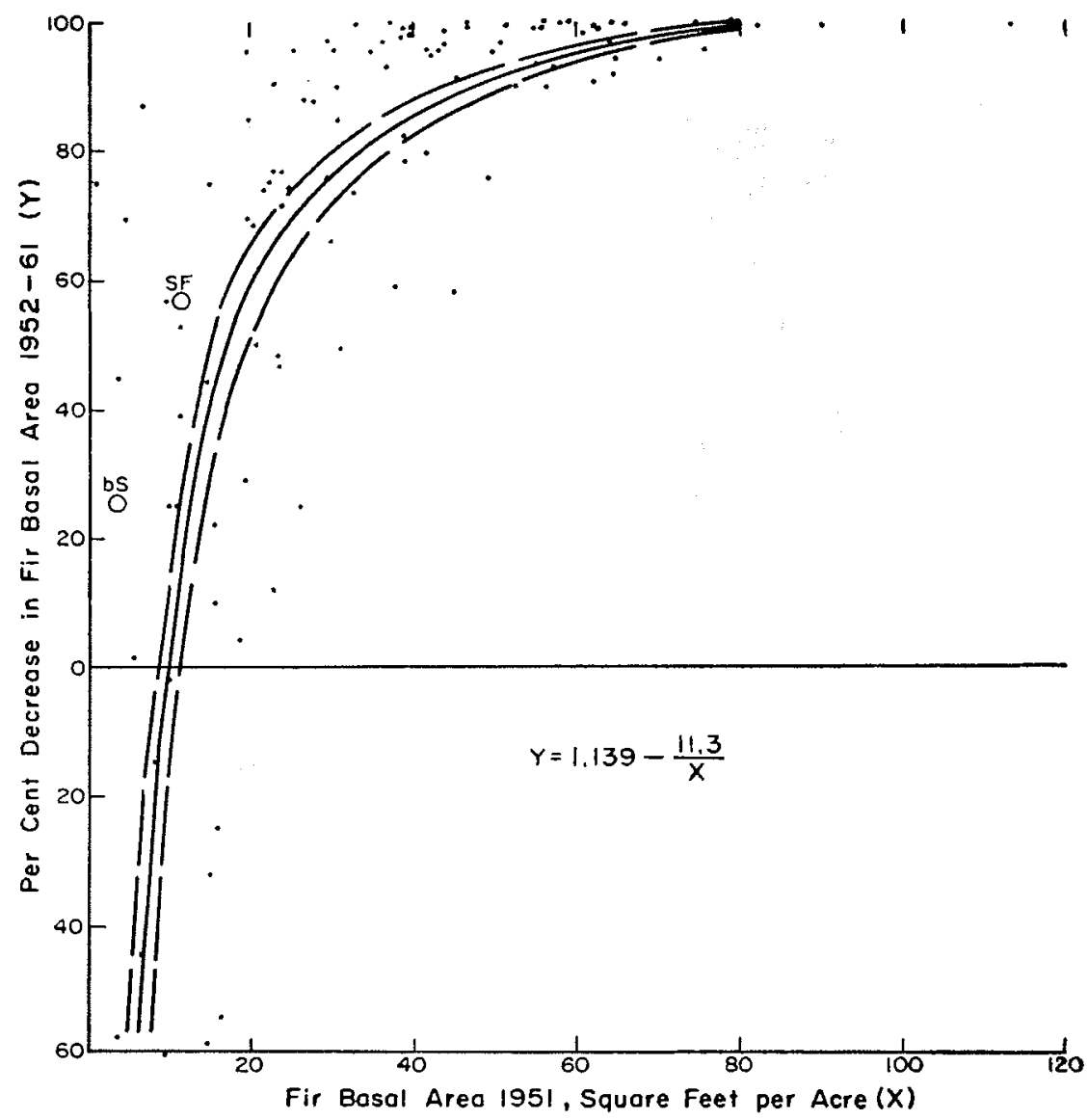

PIGURE 4. Relationship of per cent fir basal area decrease on 1951 fir basal area for a range of 0 to 80 sq. $\mathrm{ft}$. for $106 \mathrm{SFwB}$ plots, and a confidence band for the line at the 95 per cent limit.

two-inch fir actually increased during the 1951-61 decade, although this increase was much less than those noted in similar stands not attacked by the budworm (Hatcher 1960). The residual spruce and fir saplings alone would not provide well-stocked future stands but when the number of seedlings is taken into account total stocking of seedlings and saplings per acre amounts to between 1,420 and 1,850 .

\section{Discussion}

Fir mortality in immature stands began only after an estimated 5 to 7 years of budworm feeding, a number of years that has proved equally lethal in mature fir stands (Belyea 1952, Blais 1958, Craighead 1924, McLintock 1955). Although two short periods of high budworm population were 
responsible for this mortality, the fir trees apparently recovered very little if at all during the four years following the first period of attack (Figure 1). Fir volume'reductions were proportionally about equal to reductions observed elsewhere in mature stands. The numbers of fir saplings were greatly reduced over most of the area, in spite of an apparent greater resistance to damage exhibited by these smaller fir trees.

In assessing the total destruction caused by the budworm the future potential of these stands must be examined. As expected, increased numbers of hardwoods are evident in both mixedwood types but these increases are not believed to be large enough to jeopardize the development of the 1,420 to 1,850 conifer stems per acre into operable pulpwood stands. Fir seedlings are shade-tolerant and are known to survive severe competition after logging (Hatcher 1960, Ray 1956), even though their development may be somewhat retarded (Vincent 1956). The discovery that, in spite of high mortality, up to 1,850 conifer seedlings and saplings managed to survive parallels the findings of Blais (1954) in mature stands and apparently represents a typical recovery in stands where seedlings and saplings are abundant when a budworm outbreak begins.

Spruce resisted the budworm attack better than fir, a finding that corroborates those of other investigators (Blais 1954, Craighead 1925, de Gryse 1944, McLintock 1947, Turner 1954). However, it remains to be seen whether spruce will maintain its newly-gained position; evidence gathered in other areas suggests that it may not (Ghent et al. 1957, Graham and Orr 1940).

A number of workers (Balch 1946, Blais 1958, Craighead 1925, Graham and Orr 1940) have come to the conclusion that immature fir stands, while not necessarily immune to attack by the spruce budworm, are usually more resistant to damage than mature or overmature stands. The immature stands at Vermillion River represent a very small portion of the outbreak area which extended across Quebec. Therefore, the degree of damage to which these stands were subjected is not necessarily representative of what occurred in immature stands elsewhere in the province, particularly when considering the additional fact that budworm damage may vary greatly between regions and even within a given region (Craighead 1924, Ghent et al. 1957, Turner 1952). However, it is evident that at least some stands of immature fir can suffer severe losses through budworm defoliation.

Turner (1952) discovered that in mature stands, fir mortality increased with larger initial fir basal area. In the present study the results indicate the relationship is stronger between percentage change in fir basal area over a period of years and initial fir basal area (Figure 4). For studies of budworm damage to young stands, per cent change in fir basal area is perhaps a better measure of the total budworm effect than per cent mortality because the former includes the balancing effects of seedling ingrowth.

In view of the economic implications, additional research is required to establish the degree of resistance of young fir stands to budworm damage. In particular, damage in 25 to 40 -year old stands should be studied 
because the fir seedlings which have provided the future stocking in devastated mature stands, and in the immature stands of this study, are generally absent in stands of this age range. This research also is important in view of the recommendation that the conversion of extensive areas of mature fir into patches of mature and immature stands could be used as a measure that would reduce susceptibility and vulnerability to budworm attack (Blais 1964, Turner 1952).

\section{SOMMAIRE}

Le présent travail a trait aux effets de l'infestation par la tordeuse des bourgeons de l'épinette (Choristoneura fumiferana)qui, entre 1945 et 1957, infesta des peuplements immatures d'épinette noire, d'épinette-sapin et d'épinettesapin-feuillus couvrant une superficie de 1,800 acres à quelque 90 milles au nord-ouest de Trois-Rivières, dans le Québec (section forestière B-7). On avait exploité cette forêt pour ses bois à pâte, les résineux, entre 1932 et 1934. On procéda à un inventaire en 1951, puis en 1961. L'intensité de ce travail fut de 1 p. cent et comporta l'établissement systématique de 146 places d'étude permanentes de 1/10 d'acre échelonnées le long de virées parallèles.

Une abondante régénération de conifères suivit la coupe effectuée dans les années trente. Cependant, la tordeuse défeuilla gravement le sapin et en réduisit le nombre de $64 \mathrm{p}$. cent dans le principal type de peuplement qui, vers 1961 , couvrait 69 p. cent de la superficie à l'étude. Les pertes de volume dans ces jeunes peuplements étaient en proportion égales à celles que d'autres ont rapportées à l'endroit de peuplements murs de sapin.

On a trouvé pour le principal type de couvert que la réduction en surface terrière du sapin entre 1951 et 1961 était fonction de ce qu'elle était en 1951. Cependant, on n'a pu établir de relation entre les pertes et la proportion de sapin dans les peuplements.

La mortalité a été plus faible chez les peuplements mélangés que chez les résineux, quand la surface terrière en sapin était plutôt faible. Dans tous les types de couvert, l'épinette a été moins affectée que le sapin et sa proportion a augmenté dans trois des quatres types.

Les petits sapins ont mieux résisté que les gros, il est vrai, mais dans l'ensemble, les jeunes peuplements ont subi beaucoup de dommages. En dépit de la mortalité élevée parmi les petits arbres, de 1,420 a 1,850 tiges d'épinettes et de sapin à l'acre ont survécu à l'infestation. La concurrence offerte par les arbustes est grande, mais on croit que ce nombre de tiges est suffisant pour qu'on obtienne en moins de 60 ans des peuplements de bois à pâte exploitables.

Les résultats de cette ếtude sont résumés brièvement comme suit:

$1^{\circ}$ Le sapin baumier dans une superficie de 2.8 milles carrés constituée de peuplements immatures a été gravement endommagé par la tordeuse des bourgeons de l'épinette.

$2^{\circ}$ La diminution en surface terrière du sapin dépendait de la surface terrière originale de l'essence.

$3^{\circ}$ Les petits sapins se sont montrés plus résistants que les gros.

$4^{\circ}$ L'épinette a subi moins de dommages que le sapin.

$5^{\circ}$ Quand la surface terrière en sapin était faible dans les peuplements originaux, les peuplements mélangés ont résisté un peu mieux que les peuplements purs de résineux. 
$6^{\circ}$ Il est probable qu'assez d'épinettes et de sapins ont survécu pour qu'on obtienne une récolte de bois à pâte avant 60 ans.

$7^{\circ}$ Des recherches plus poussées sont nécessaires pour mettre en lumière la relation qui existe entre l'âge du peuplement et l'étendue des dégâts causés par la tordeuse des bourgeons de l'épinette, particulièrement entre 25 et 40 ans.

\section{REFERENCES}

BALCH, R. E. 1946. The spruce budworm and forest management in the Maritime provinces. Can. Dept. Agric., Ent Div., Proc. Pub. No. 60.

BELYEA, K. M. 1952. Death and deterioration of balsam fir weakened by spruce budworm in Ontario, Part II. An assessment of the role of associated insect species in the death of severely weakened trees. J. For. 50: pp. 729-738.

BLAIS, J. R. 1954. The recurrence of spruce budworm infestations in the past century in the lac Seul area of Northwestern Ontario. Ecol. 35 (1): pp. 62-71.

BLAIS, J. R. 1958. The vulnerability of balsam fir to spruce budworm attack in Northern Ontario, with special reference to the physiological age of the tree. For. Chron. 34 (4): pp. 405-422.

BLAIS, J. R. 1964. Account of a recent spruce budworm outbreak in the Laurentide Park region of Quebec and measures for reducing damage in future outbreaks. For. Chron. 40 (3): pp. $313-323$.

CRAIGHEAD, F. C. 1924. Studies of the spruce budworm (Cacoecia fumiferana Clem.) Part II. General bionomics and possibilities of prevention and control. Can. Dept. Agric. Tech. Bull. 37.

CRAIGHEAD, F. C. 1925. Relation between mortality of trees attacked by the spruce budworm (Cacoecia fumiferana Clem.) and previous growth. J. Agr. Res .30: pp. 541-555.

DE GRYSE, J. J. 1944. Enemies of the forest - man or insect? Proc. Roy. Can. Inst. Ser. III A, 9: pp. 52-62.

GHENT, A. W., D. A. FRASER and J. B. THOMAS. 1957. Studies of regeneration in forest stands devastated by the spruce budworm. For. Sci. 3, pp. 184-207.

GRAHAM, S. A. and L. W. ORR. 1940. The spruce budworm in Minnesota. Univ. of Minn. Agric. Exp. Sta., Tech. Bull. 142.

HATCHER, R. J. 1960. Development of balsam fir following a clearcut in Quebec. Can. Dept. Northern Affairs and National Resources, For. Br., For. Res .Div., Tech. Note 87.

McLINTOCK, T. F. 1947. Silvicultural practices for control of spruce budworm. J. For. 45: Pp. $655-658$.

1955. How damage to balsam fir develops after a spruce budworm epidemic. U.S. Dept. Agric., For. Sery., Ntheast For. Exp. Sta., Sta. Paper 75.

PILON, J. G. and J. R. BLAIS. 1961. Weather and outbreaks of the spruce budworm in the Province of Quebec from 1939 to 1956. Canad. Ent. 98: pp. 118-123.

RAY, R. G. 1948. A preliminary report on the reproduction survey, Quebec, 1946-1947. Northeastern Coniferous Section B-1, Boreal Forest Region. Can. Dept. Mines and Resources, unpublished MS.

1956. Site-types, growth and yield at the Lake Edward Forest Experimental Area, Quebec. Can. Dept. Northern Affairs and National Resources, For. Br., For. Res. Div., Tech. Note 27.

ROWE, J. S. 1959. Forest regions of Canada. Can. Dept. Northern Affairs and National Resources, For. Br. Bull. 123.

TURNER, K. B. 1952. The relation of mortality of balsam fir, Abies balsamea (L.) Mill, caused by the spruce budworm, Choristoneura fumiferana (Clem.), to forest composition in the Algoma forest of Ontario. Can. Dept. Agric., Pub. 875.

VINCENT, A. B. 1956. Balsam fir and white spruce reproduction on the Green River watershed. Can. Dept. Northern Affairs and National Resources, For. Br., For. Res. Div., Tech. Note 40 .

1962. Development of balsam fir thickets in the Green River watershed following the spruce budworm outbreak of 1913-1919. Dept. of Forestry, Canada, For. Res. Br. Tech. Note 119. 